\title{
Multi-professional team's perception of nurses' competences in liver transplantations
}

\author{
Percepção da equipe multiprofissional sobre as competências do enfermeiro no transplante hepático \\ Percepción del equipo multiprofesional sobre las competencias del enfermero en el trasplante hepático
}

\section{Francisca Diana da Silva Negreiros', Alice Maria Correia Pequeno", José Huygens Parente Garcia"', Maria Isis Freire de Aguiar'v', Tatiana Rebouças Moreira', Maria José Nascimento Flor'}

\author{
' Universidade Federal do Ceará, Walter Cantídio University Hospital. Fortaleza, Ceará, Brazil. \\ "Universidade Estadual do Ceará, Vocational Master's Course in Health Teaching. Fortaleza, Ceará, Brazil. \\ II' Universidade Federal do Ceará, College of Medicine, Surgery Department. Fortaleza, Ceará, Brazil. \\ "v Universidade Federal do Ceará, Nursing Department. Fortaleza, Ceará, Brazil.
}

\section{How to cite this article:}

Negreiros FDS, Pequeno AMC, Garcia JHP, Aguiar MIF, Moreira TR, Flor MJN. Multi-professional

team's perception of nurses' competences in liver transplantations. Rev Bras Enferm [Internet]. 2017;70(2):242-8.

DOI: http://dx.doi.org/10.1590/0034-7167-2016-0223

\section{Submission: 06-06-2016 Approval: 09-02-2016}

\begin{abstract}
Objective describe the multi-professional team's perception of nurses' competences in liver transplantation programs. Method: descriptive study with a qualitative approach. Data were collected through a questionnaire. Participants were 12 professionals of the liver transplantation team of a reference hospital. For result interpretation, the thematic analysis technique was employed. Results: the professionals assessed the competences employed by nurses as proactive, autonomous, creative, humanized, capable of teamwork, decision-making and conflict management. Conclusion: this study made it possible to demonstrate that members of the multi-professional team perceived nurses as professionals capable of coordinating and integrating the skills "knowing, doing, being and co-existing", enabling quality care for candidates and receivers of liver transplants, as well as for their families and/or caregivers in all perioperative phases.
\end{abstract}

Descriptors: Patient Care Team; Liver Transplantation; Nurses; Nurse's Role; Professional Competence.

\section{RESUMO}

Objetivo: descrever a percepção da equipe multiprofissional sobre as competências do enfermeiro no programa de transplante hepático. Método: estudo descritivo com abordagem qualitativa. Os dados foram coletados por meio de questionário com participação de 12 profissionais da equipe do transplante hepático de um hospital de referência. Para interpretação dos resultados, utilizou-se a técnica de análise temática. Resultados: os profissionais avaliaram as competências desenvolvidas pelo enfermeiro como proativa, autônoma, criativa, humanizada, que sabe trabalhar em equipe, tomar decisões e administrar conflitos. Conclusão: este estudo possibilitou revelar que os membros da equipe multiprofissional percebiam o enfermeiro como um profissional capaz de articular e integrar os saberes "conhecer, fazer, ser e conviver", possibilitando uma assistência com qualidade ao candidato e ao receptor de transplante hepático, como também aos seus familiares e/ou cuidadores em todas as fases do perioperatório.

Descritores: Equipe de Assistência ao Paciente; Transplante de Fígado; Enfermeiros; Papel do Profissional de Enfermagem; Competência Profissional.

\section{RESUMEN}

Objetivo: describir la percepción del equipo multiprofesional sobre las competencias del enfermero en el programa de trasplante hepático. Método: estudio descriptivo, con abordaje cualitativo. Datos recolectados mediante cuestionario, con la participación de 12 profesionales del equipo de trasplante hepático de un hospital de referencia. Para la interpretación de resultados, se utilizó técnica de análisis temático. Resultados: los profesionales evaluaron las competencias desarrolladas por el enfermero como proactiva, autónoma, creativa, humanizada, que sabe trabajar en equipo, tomar decisiones y administrar conflictos. Conclusión: este estudio permitió revelar que los miembros del equipo multiprofesional percibían al enfermero como un profesional capaz de articular e 
integrar los saberes "conocer, hacer, ser y convivir", permitiendo una atención de calidad al candidato y al receptor de trasplante hepático, así como también a sus familiares y/o cuidadores en todas las fases del perioperatorio.

Descriptores: Grupo de Atención al Paciente; Trasplante de Hígado; Enfermeros; Rol de la Enfermera; Competencia Profesional.

\section{CORRESPNDING AUTHOR Francisca Diana da Silva Negreiros E-mail: negreiros.diana@gmail.com}

\section{INTRODUCTION}

Solid organ transplantation is a therapeutic option to improve the quality of life of individuals in any age group who suffer from irreversible final stage chronic diseases in the final stage ${ }^{(1)}$. Liver transplantation is considered one of the most complex procedures in modern surgery. Its success depends on a complete hospital infrastructure, in addition to a multidisciplinary team skilled to care for severely debilitated and immunosuppressed patients ${ }^{(2)}$.

One of the nurses' roles in the transplantation processes is integrating the multi-professional team, collaborating in the performance of care. Thus, these professionals are constantly encouraged to deliver quality care for patients submitted to transplantations, contributing for their success. The complexity of care has been increasing and length of stay has been decreasing. In this sense, nurses have to provide high level care, both to patients and their families or caregivers, enabling the continuity of care in the home environment ${ }^{(1)}$.

Nurses are key elements to the establishment of a successful transplantation program. For that end, they have to develop essential competences to act in the different phases of the perioperative period. Competence is defined as "the capacity to apply specific knowledge, abilities, attitudes and values to the performance standard demanded in a specific context"(3).

When searching databases for scientific data, a review was conducted on the content of the Virtual Health Library (BVS), that addressed the research theme, using the following health science descriptors (DeCS): "Patient Care Team" and "Liver Transplantation" and "Nurses", and no publications were found. When searched in the United States National Library of Medicine (PUBMED), the descriptors "Patient Care Team" and "Liver Transplantation" and "Nurses" in the Medical Subject Headings (MESH) version, only a single article was found mentioning patient education after liver transplantation, in the year of 2007.

Therefore, this study is needed due to the lack of research focusing on this theme and the need to recognize the role of nurses in transplantations in relation to the team, the institution and the community. This study's development was motivated by the need to respond to the following research question: "What is the multi-professional team's perception of nurses' competences in liver transplantation?" Starting from those considerations, the objective was to describe the multi-professional team's perception of nurses' competences in the liver transplantation program.

\section{METHOD}

\section{Ethical aspects}

This research followed the guidelines of Resolution 466/2012 of the National Health Council, and only began after approval by a research ethics committee, under Certificate of Submission for Ethical Appreciation. All participants received an explanation of the research and signed a free and informed consent form. Subjects names were presented as numbers, according to the chronological order of questionnaire delivery, followed by the acronym MT, for multi-professional team (1MT, $2 \mathrm{MT}, \ldots, 12 \mathrm{MT})$, ensuring their privacy during the whole research process.

\section{Theoretical-methodological framework and study type}

A descriptive study, using a qualitative approach, was conducted having content analysis as its theoretical framework for data analysis ${ }^{(4)}$.

\section{Methodological procedures}

\section{Study setting}

The study was carried out at a reference hospital for liver transplantations in the state of Ceará, Brazil.

\section{Data sources}

The sample comprised 12 professionals who worked in the liver transplantation service. Participating categories were physician, nutritional therapist, physical therapist, social assistant, psychologist, physical therapy and social work residents who were attending the Multi-professional Integrated Residency Program in Hospital Health Care, from the area of care concentration in transplantation, with the aim of offering concepts on nurses' practices in the liver transplantation process.

Inclusion criteria for members of the multi-professional team and residents were participating in the liver transplantation service and accepting to participate in the research.

\section{Data collection and organization}

Data were collected from June to August, 2014, through responses to a questionnaire with the following guiding question: "What do you think of nurses' practice in the liver transplantations process? Describe your opinion emphasizing its potentials and vulnerabilities". After these professionals' authorization, the instrument was delivered to participants and returned to the researcher after being filled in.

\section{Data analysis}

Responses were submitted to thematic analysis, following the phases of pre-analysis, material exploration, treatment of results and interpretation ${ }^{(4)}$. The process of information analysis brought to light two categories: "Nurses in the multi-professional liver transplantation team: care integrated through communication skills" and "Knowledge and practices of nurses in liver transplantation: potentials and vulnerabilities in the eyes of the multi-professional team". 


\section{RESULTS}

Based on the participants' speeches, nurses' competences in the transplantation service were identified in two categories: "Nurses in the multi-professional liver transplantation team: care integrated through communication skills" and "Knowledge and practices of nurses in liver transplantation: potentials and vulnerabilities in the eyes of the multi-professional team".

Nurses in the multi-professional liver transplantation service: care integrated through communication skills

According to the subjects, nursing professionals were those mainly responsible for coordinating the multidisciplinary team's work, with their open and clear communication skills, aiming to people's various needs with quality, focusing on holistic care for each patient's individual and collective contexts, addressing the biopsychosocial dimension.

Within the multi-professional team, nurses are the professionals who follow all stages of transplantations, along both patients and the team. They can link all professionals for patient care, both before and after transplantations in the clinic sphere, as well as during the hospital stay. Along with the team, they can establish communication and bonds. (12MT)

Nurses can be said to be the professionals who most coordinate communication with the other team members, because they always talk to physical therapists, nutritional therapists, social assistants, physicians, pharmacists and other professionals, looking to solve patients' problems. (3MT)

It was clear, in this study, that communication shared among members of the multi-professional team allowed them to exchange information related to the patients' health/disease conditions, so they could adopt adequate practices according to each identified need. Thus, nurses actively participated in meetings and group practices with the health team.

The nurses can practice while considering all areas in which patients need care, contributing for the development of comprehensive actions. (7MT)

The professionals present an interdisciplinary approach, acting in harmony with the other categories. (9MT)

They follow and monitor interventions conducted by the other professionals: physicians, social workers, psychologists and nutritionists. Nurses are active participants [in] all meetings of the multi-professional team on Thursdays. They always offer feedback on pending subjects from previous meetings and on whatever was concluded or not concluded during the week. This is very helpful for care continuity. (10MT)

During nursing seminars and consultations, nurses handed out brochures so that patients and families could refer to those guidelines. This is written verbal communication.

Depending on the nursing consultation or seminar, the nurses hand out written guidelines to families and patients. Since there is so much information to assimilate, this helps. (5MT)
Throughout the whole transplantation process, patients receive information adapted to their culture and understanding. They also take everything home in written so they can clear any doubts if needed. (8MT)

Participants reported that nurses, when addressing patients and/or family members, employed non-verbal communication in an embracing manner, through gestures of sympathy, balance, respect, visual contact and active listening, which are essential elements to maintain well understood and valued communication, enabling patients and family members to feel confident and comfortable when expressing their feelings and doubts.

I observed that nurses knew how to listen and speak at appropriate times, demonstrating empathy and firmness at embracement and when conducting nursing seminars and consultations. (11MT)

Nurses make patients and families comfortable to speak out their fears, they let them speak everything they felt and knew about transplantations; afterwards, the nurses explained all stages of surgery in an affective and clear manner. This makes patients confident and calm. (7MT)

Knowledge and practices of nurses in liver transplantation: potentials and vulnerabilities in the eyes of the multiprofessional team

Participants were unanimous when asserting that nurses were the health team members who were closest to patients and families, from their enrollment in the waiting list until their follow-up after the transplantation. Thus, nurses enable patients, at all stages - pre/trans/postoperative of liver transplantations - to receive safe and humanized care through guidelines, embracement and nursing consultations, with the goal of clearing doubts and reducing anxiety and fears.

The nurses' role is very important, since they are the professionals who are beside patients 24 hours a day; monitoring, embracing, making each stage of the transplantation process safer and with the least possible harm. They ensure higher quality in the process. (8MT)

I see that their role also becomes crucial when embracing patients since their first contact with our transplantation center. This embracement, especially for patients coming from other states, is important to communicate safety and care for them, in addition to clearing common doubts in this process, general guidelines and referrals. (12MT)

Based on the subjects' speeches, direct care from nurses to patients aimed at health education, favoring a trustful and participative relationship. As a result, it contributed for better post-surgery recovery, supporting patient awareness of treatment adherence and their empowerment for self-care, as well as motivating family members to perform home care and to accept the new life style.

I believe that nurses perform a role of the highest importance in this process, because it might be the most complex procedure in all medicine. Nurses must act since the care stage, such as in the surgery center, collection, clinics 
since the embracement process, guidance and acceptance facilitation of and adherence to the transplantation, thus, similarly to the service management process. (2MT)

Direct and daily contact with patients and companions enable a broad knowledge of their reality and which demands are priorities. It is their perception applied to the user, beyond physiologism. (9MT)

The participants mentioned that both direct and indirect care to individuals are relevant attributions in the nurses' work environment, enabling positive transplantation performances from the business and care perspectives.

The nursing team at the liver transplantation clinic carries the important task of managing the clinic itself daily, dealing not only with patient care, but also with all bureaucratic aspects concerning transplantations. (4MT)

Nursing also has an important role in the management and embracement of liver-receiving patients; in the organization of exams; as well as in the ward, in monitoring medical visitations and in organ collections. (6MT)

Among potential activities performed by nurses, the service teaching/research competence was emphasized by participants as a health action that strengthened the various skills (knowing, doing, being and co-existing) of nurses, aiming for comprehensive, engaged, and effective care, in conjunction with the professionals and residents involved in transplantations processes.

It is crucial that these professionals obtain the skills to work with transplant patients. I see that nurses participate in congresses and offer trainings for students or professionals from their own hospitals or from other locations. (1MT)

The development of research in the field of transplantations also depends on nursing professionals for data provision and logistics, so that it can be developed by the team. Nurses also hold an educational role toward patients and families, guiding them on the legislation that standardizes transplantations and procedures before, during and after transplantations. For that, nurses must be up to date and qualified. (12MT)

Nurses are also committed to teaching and monitoring professionals such as residents and other institutions' students by transmitting their knowledge on transplantation, which is a very specific field. (3EM)

When reflecting on possible vulnerabilities in the service's daily routine and with the various management and care activities that are the nurses' responsibilities, the members of the multiprofessional team mentioned that work overload and physical and mental stress can affect the quality and safety of care for patients.

I believe that their vulnerability is the high workload that nurses' receive. (1MT)

Because it is a high complexity procedure, physical and mental stress become severe for those involved, because any error can lead to catastrophic events. (2MT)
On vulnerabilities, I believe that work overload negatively impacts activity performance and care humanization, especially in wards. (7MT)

\section{DISCUSSION}

These study's results demonstrate that nurses used the communication skill verbally and non-verbally when searching to integrate and better perceive information from the team, patients and families, improving the performance of their administrative and care tasks, as well as promoting positive outcomes throughout the whole liver transplantation process.

Communication is a crucial tool employed in nursing care; in other words, an instrument that enables the relationship between the team and patients; one cannot imagine nursing activity without mentioning the importance of communication for the patients' well-being and reestablishment ${ }^{(5)}$. Therefore, communication is an essential basic instrument for care, working as the basis for interpersonal relationships. In order to establish effective communication, the team must be capable and involved, aiming to establish this relationship and understand that it is crucial to recognize patients as subjects of care $^{(6)}$.

Regarding communication among professionals, nurses were seen as links among the other professionals and patients, as well as among patients and health professionals. They are in the center of communication and perform a crucial role in facilitating professional communication ${ }^{(7)}$. In hospital environments, this involves the relationships of health professionals with others, as well as their knowledge and skill exchange for informed clinical decision making for patient care. On the other hand, inadequate professional communication can compromise care quality.

Still in this scope, research participants recognize that nurses are the professionals who are beside patients 24 hours a day, caring for their well-being and comfort through therapeutic communication, thus being able to communicate the patients' actual needs to the team. In comparison to other health professionals, nurses have a closer relationship with patients, since they spend most of their time with them and, therefore, are in the forefront of communication, acting as mediators of the patient-physician relationship; as a link between these, they can influence processes of diagnosis, treatment and healing for patients. In this sense, nurses, as key-members of the health team, need to establish effective professional communication with other health members in order to offer safe and quality care $^{(7)}$.

This study's data strongly demonstrate that, among the nurses' different practices, there is the performance of health education, which involves both patients and their families, focused on explaining all procedures to which they will be submitted, starting with their enrollment in the single queue, until postsurgery clinic follow-up, seeking to make patients aware of treatment acceptance and empowered for self-care, as well as encouraging families to engage more actively with care at their homes and better receive life habit transformations caused by the health/disease conditions experienced by patients.

Health education is one of the fundamental competences of nurses in transplantation services. A study conducted in the liver transplantation ward of the Clinics Hospital of the 
Ribeirão Preto Faculty of Medicine, at University of São Paulo, found that the main information needs of transplant candidates were precautions before the transplantation, complications and necessary care in post-surgery ${ }^{(8)}$. Education for transplantation patients is a continuous action and must serve users and families in the development of the transplantation process. It is related to possible changes in life style, providing patients and families tools for: clear decision making; behavior change towards a healthy life style; focus on wellbeing and informational goals. Proper involvement of families/companions in the learning process can support anxiety relief and improve ties with the patients' health state ${ }^{(9)}$.

Competences of clinic nurses in transplantations during the perioperative period involve knowledge and abilities for: providing education for patients related to perioperative procedures and post-surgery healing; participating in the transplantation process according to the protocols of the transplantations center; obtaining necessary results of presurgical tests; and collaborating with transplantation teams at the time of patient admission and whenever necessary ${ }^{(10)}$.

Nurses' education in transplantations involve their own education, that of other healthcare providers and that of the general public. In order to teach other people, nurses must keep their knowledge, skills and attitudes constantly up-to-date, especially in a complex and unstable field such as transplantation ${ }^{(9)}$. Education, in the sphere of health organizations, must be stimulated with case studies, debates among professionals, simulations and with newcomer nurses being monitored by competent nurses, who are proficient and experts. Therefore, clinical practice beginners would have a reference professional at the institution, whereas veterans would be appreciated for their level of competence ${ }^{(11)}$.

Nurses are responsible for a variety of management and care actions in the hospital environment. A study conducted with nurses of a university hospital in Finland, using the instrument Nurse Competence Scale (NCS), found that, among the 458 nurses, the highest scoring responses were those related to the role of care (68.4) and situation management $(67.5)^{(12)}$. In a program for the development of clinical leadership conducted in Ireland, participants chose the following as main necessary competences for the function: quality and safety, clinical excellence, self-conscience, decision-making and communication ${ }^{(13)}$. In this view, nurses must acquire basic competences in order to preserve the quality of procedures that are part of liver transplantations, promoting higher control and prevention of adverse events.

Nursing practice in the transplantation service involves a variety of care and management activities. As such, nurses who take on the role of transplantation coordinators need to have wideranging knowledge to manage the complex situations that arise in patient care throughout the different phases of transplantation and to develop the following abilities: clinical assessment focused on signs and symptoms of rejection and infection, complications associated with transplantations, pharmacological interactions; communication with patients, families and other members of the transplantations team; and teaching-learning, organizational, screening, administrative and problem-solving skills ${ }^{(14)}$.
In this perspective, nurses who are involved in patient care have to take part in multi-professional administrative and scientific meetings for transplantation research. In these meetings, professionals present and discuss themes related to the therapy type suitable to patients' general state, teaching/research strategies and other subjects ${ }^{(11)}$.

Hence, nurses practicing in the transplantation field, especially liver, must have essential competences for the promotion of effective and safe care. As liver transplantations are considered high-complexity procedures, it is expected from professionals that they keep up-to-date with scientific breakthroughs and cutting-edge technology. For that end, they must continuously seek training and refresher courses, which are crucial for daily tasks. They should also offer teaching-learning to students, professionals and communities and all of those who are interested in aspects related to transplantations.

Regarding the vulnerability of tasks carried out by nurses, this study's participants asserted that work overload, mental and physical stress could lead to lower service quality. It is crucial that all professionals work safely, in complete harmony with themselves and others; for such, they have to carry out their functions in an adequate and healthy environment, with a work schedule that fits the performed competences and their physical capacities.

Studies confirm that most nursing professionals face difficulties in their daily practice such as work overload, intense work rhythm, materials that are not sufficient in quantities and quality, lack of personnel, extended working hours, physical and mental stress among other issues that hamper the adequate performance of care for patients who are under their responsibilities ${ }^{(15)}$.

In this study, work overload for nursing professionals was pointed as a risk factor for patient safety, directly interfering in care quality. In agreement with these results, an observational cohort study conducted at two high-complexity teaching hospitals in the cities of Ribeirão Preto and São Paulo demonstrated that, for both hospitals, there was work overload and that incidents without lesions and adverse events were associated with nursing personnel work overload $(p<0.0001)^{(16)}$.

Nurses have the responsibility of managing a large number of professionals, and it has been a challenge to not only calculate the size of the nursing team, but also distribute it according to the units' necessities. The competences required by organizations and each nurse's potential to develop them can be strategic to coordinate the units' workload with their profiles, aiming for better results in terms of care $^{(11)}$.

With this in mind, it can be said that the professionals assessed competences employed by nurses as proactive, autonomous, creative, humanized, capable of teamwork, decision making and conflict management. Therefore, the professionals consider the nurses' work as competent and fundamental for the success of liver transplantations. They also emphasized the importance of the system organization through administrative management, the development of 
teaching/research, enabling growth, recognition and dissemination of service, as well as its active participation in interactions with professionals of various specialties. This promotes integrated care that is safe and holistic to patients and families, contemplating physiological, psychological and social aspects.

According to what has been presented, it can be briefly defined, according to Chart 1 , that nurses have knowledge, abilities and attitudes to perform activities in liver transplantations.

Chart 1 - Competences of nurses in the perception of the multi-professional liver transplantation team, Fortaleza, Ceará, Brazil, 2014

\begin{tabular}{|l|l|}
\hline \multicolumn{2}{|c|}{ COMPETENCES } \\
\hline \multirow{4}{*}{ Knowledge } & Specific technical and scientific \\
\cline { 2 - 3 } & Legislation (Decrees and resolutions) \\
\cline { 2 - 3 } & Service management \\
\cline { 2 - 3 } & Teaching/learning process \\
\hline \multirow{4}{*}{ Ability } & Teamwork \\
\cline { 2 - 3 } & Communication \\
\cline { 2 - 3 } & Service organization \\
\cline { 2 - 3 } & Conflict administration \\
\cline { 2 - 3 } & Health education \\
\hline \multirow{4}{*}{ Attitude } & Availability \\
\cline { 2 - 3 } & Involvement \\
\cline { 2 - 3 } & Collaboration, trustfulness and credibility \\
\cline { 2 - 3 } & Commitment \\
\cline { 2 - 3 } & Autonomy and initiative for decision making \\
\hline
\end{tabular}

\section{Study limitations}

Although the research had a limited number of participants, which can be considered a limitation, the results found can serve as ground for further studies to enhance discussion on the perception of multi-professional teams of nurses' competences, not only in liver transplantation services, but also in other areas of nursing practice.

\section{Contributions for the nursing and health fields or public policies}

Nurses are seen as key elements for the establishment of a successful transplantation program. For that end, they have to develop essential competences to act in the different phases of the perioperative period. Thus, it is relevant to know the opinion of other professionals involved in care, seeking to offer resources for nurses to reach professional recognition in the eyes of the multidisciplinary team while practicing in the complex field of transplantations and offer higher visibility to their practice.

\section{FINAL CONSIDERATIONS}

Speeches of the multidisciplinary team professionals showed respect and recognition for the importance of nurses' work, emphasizing their knowledge of guidelines, standards and routines of the service. Moreover, they reported that nurses had autonomous and effective actions in planning, executing and supervising the patients' therapeutic care plan. They presented proactive attitudes, of leadership, empathy, interpersonal relationships and adopted care that was shared with other professional categories. Thus, they contributed to directly impact care quality aiming for a holistic assistance to patients.

Nurses are seen as professionals who enable communication inside the healthcare team, facilitating comprehensive care to satisfy real patient needs, especially because they are close to users and, therefore, more readily able to detect necessities that require solutions shared with the team.

The speeches demonstrated that nurses are crucial members of the liver transplantation team, both in coordinating and in direct patient care. However, they must participate in more scientific studies in order to disseminate their work, which will result in more professional appreciation and recognition in the perioperative setting of liver transplantation.

Work overload and physical and mental stress were mentioned by participants as factors that could interfere in nursing care quality. Considering these opinions, it is necessary for managers to design work organization strategies that meet the demands of the service, in the sense of preventing adverse events, optimizing nurse performance and ensuring safe health care.

Finally, members of the multi-professional team perceived nurses as professionals capable of coordinating and integrating the skills "knowing, doing, being and co-existing", enabling quality care for candidates and receivers of liver transplants, as well as for their families and/or caregivers at all perioperative phases.

\section{REFERENCES}

1. International Transplant Nurses Society (ITNS). Introduction to transplant nursing: core competencies. Pittsburg: International Transplant Nurses Society, ITNS; 2011.

2. Pereira WA. Manual de Transplantes de Órgãos e Tecidos. 4 ed. Belo Horizonte: Coopmed; 2012.

3. Australian Health Promotion Association's (AHPA). Core competencies for health promotion practitioners. Management Committee at their National Teleconference meeting on Thursday 5th February; Queensland, 2009.

4. Minayo MCS. O desafio do conhecimento: pesquisa qualitativa em saúde. 13ª ed. São Paulo: Hucitec; 2013. 
5. Gaspar MRF, Massi GA, Gonçalves CGO, Willig MH. Nursing team and communication with tracheostomized patients. Rev CEFAC[Internet]. 2015[cited 2016 Apr 27];17(3):734-44. Available from: http://www.scielo.br/pdf/rcefac/v17n3/en_1982-0216-rcefac-17-03-00734.pdf

6. Broca PV, Ferreira MA. Equipe de enfermagem e comunicação: contribuições para o cuidado de enfermagem. Rev Bras Enferm[Internet]. 2012[cited 2015 Jul 10];65(1):97-103. Available from: http://www.scielo.br/pdf/reben/v65n1/14.pdf

7. Ghiyasvandian S, Zakerimoghadam M, Peyravi H. Nurse as a facilitator to professional communication: a qualitative study. Glob J Health Sci. 2015;7(2):294-303.

8. Mendes KDS, Rossin FM, Ziviani LC, Castro-e-Silva O, Galvão CM. Information needs of liver transplant candidates: the first step of the teaching-learning process. Rev Gaúcha Enferm[Internet]. 2012[cited 2016 Feb 24];33(4):94-102. Available from: http://www.scielo.br/pdf/ rgenf/v33n4/en_12.pdf

9. Ohler L, Cupples SA. Core Curriculum for Transplant Nurses. Philadelphia. Mosby Elsevier; 2013.

10. Natco The Organization for Transplant Professionals. Core Competencies for the Clinical Transplant Nurse. Natco; 2010.

11. Numminen O, Meretoja R, Isoaho H, Leino-Kilpi H. Professional competence of practising nurses. J Clin Nurs[Internet]. 2013 [cited 2015 Jul 10];22(9-10):1411-23. Available from: http://onlinelibrary.wiley.com/doi/10.1111/j.1365-2702.2012.04334.x/epdf

12. Patton D, Fealy G, McNamara M, Casey M, Connor TO, Doyle L, et al. Individual-level outcomes from a national clinical leadership development programme. Contemp Nurse[Internet]. 2013[cited 2015 Jul 10];45(1):56-63. Available from: http://www.tandfonline.com/ doi/abs/10.5172/conu.2013.45.1.56

13. Mendes KDS, Roza BA, Barbosa SFF, Schirmer J, Galvão CM. Organ and tissue transplantation: responsibilities of nurses. Texto Contexto Enferm[Internet]. 2012[cited 2016 Feb 20];21(4):945-53. Available from: http://www.scielo.br/pdf/tce/v21n4/en_27.pdf

14. Aued GK, Bernardino E, Peres AM, Lacerda MR, Dallaire C, Ribas EN. Clinical competences of nursing assistants: a strategy for people management. Rev Bras Enferm[Internet]. 2016[cited 2016 May 3];69(1):130-7. Available from: http://www.scielo.br/pdf/reben/v69n1/ en_0034-7167-reben-69-01-0142.pdf

15. Ramos EL, Souza NVDO, Gonçalves FGA, Pires AS, Santos DM. Quality of work life: repercussions for the health of nursing worker in intensive care. Rev Pesq: Cuid Fundam[Internet]. 2014[cited 2016 May 10];6(2):571-83. Available from: http://www. seer.unirio.br/index.php/cuidadofundamental/article/view/2833/pdf_1244

16. Novaretti MCZ, Santos EV, Quitério LM, Daud-Gallotti RM. Sobrecarga de trabalho da Enfermagem e incidentes e eventos adversos em pacientes internados em UTI. Rev Bras Enferm[Internet]. 2014[cited 2016 Aug 16];67(5):692-9. Available from: http://www.scielo.br/pdf/ reben/v67n5/0034-7167-reben-67-05-0692.pdf 